\title{
Termination of Domestic Workers' Employment: Unfair Labour Practice Re-visited
}

\author{
Kola O. Odeku \\ Faculty of Management and Law, School of Law, University of Limpopo, South Africa \\ Email: kooacademics@gmail.com
}

\author{
Doi:10.5901/mjss.2014.v5n10p672
}

\begin{abstract}
This paper elucidates that termination of a domestic worker by an employer is not wrong however, the paper accentuates that the termination must strictly follow due process and comply fully with the procedure and the enabling laws governing and regulating labour relations. The paper looks at the conditions and situations of domestic workers in relation to how their employments are being terminated by the employers without due regard for the workers and the law. It raises the importance of sensitising the workers in this sector about their rights in order not be unfairly terminated and dismissed by the employers. It highlights available remedies that are available to a wrongfully dismissed worker.
\end{abstract}

Keywords: Domestic workers, Unfair Labour Practice, Vulnerability, Invisibility, Remedies, Justice.

\section{Introduction}

In South Africa, those who earn their wages by providing domestic and household services to others are well protected under the constitution and the labour law (Gaitskel et al. 1983). They are described as "housekeepers, gardeners, and watchpersons, care givers and so on in private households in exchange for remuneration and/or lodging and board." (Ramirez-Machado, 2003). Even though they remain hidden and invisible to society, the number of people joining this workforce keeps increasing on a daily basis (Sexwale, 1994). The conditions under which they work and perform their labour services are, in most cases, very degrading and appalling (Mantouvalou, 2006). Ramirez-Machado (2003) points out that "domestic workers suffer from poor working conditions and that their isolation makes difficult some kind of organization which would allow them to improve their condition." This is the reason why labour law protection is so important for this category of workers. More importantly, the invisibility aspect of the work makes the employers thrive in their exploitations and abuses of domestic workers (Mashburn-Myrick, 2012). Being live-in domestic workers makes the situation worse as they are made even more invisible to the society but more susceptible to abuse by the employer. (Glantz, 2005). Glantz (2005) indicates that "its abusive and exploitative nature has prompted many authors to label domestic service as 'anachronistic' and/or 'premodern' in this age of oft-lauded modernization and globalization."

However, it is pertinent to point out that domestic work is a form of employment recognised under the law, hence, domestic workers are entitled to enjoy the protective mechanisms enshrined in the law (Fourie, 2008). More importantly, the promulgation of the Sectoral Determination 7 (SD7) under sections 51-58 of the Basic Conditions of Employment Act, No. 75 of 1997 (BCEA) strengthens the protection accorded domestic workers as they are considered vulnerable people (Smit and Fourie, 2010). Commenting on the precarious and vulnerable situations of domestic workers Fourie (2008) writes "these workers are often paid for results rather than time. Their vulnerability is linked in many instances to the absence of an employment relationship or the existence of a flimsy one. Most of these workers are unskilled or work in sectors with limited trade union organisation and limited coverage by collective bargaining, leaving them vulnerable to exploitation. They should, in theory, have the protection of current South African labour legislation, but in practice the unusual circumstances of their employment render the enforcement of their rights problematic. The majority of nonstandard workers in South Africa are those previously disadvantaged by the apartheid regime, compromising women and unskilled black workers. The exclusion of these workers from labour legislation can be seen as discrimination, which is prohibited by almost all labour legislation in South Africa. This contribution illustrates how the concept of indirect discrimination can be an important tool used to provide labour protection to these workers."

Employers could terminate any domestic workers at will based on any flimsy reasons or excuses without considering the effects and implications such termination will have on the worker (Martins, 2009). In this sector, existing literature has shown that the culture of unfair dismissal is the norm rather than the exception (Ewing, 1989). Employers perpetrate unfair labour practices against domestic workers with impunity based on the arrogant belief and conviction that 
domestic workers are meant to do the dirty jobs, get disposed of and dismissed at will depending on the whims and caprices of the bosses (Vosko, 2000). Horton and Vilani quoted in Du Toit (2010:215) points out that "while gains have been made in terms of legislation, such as the BCEA and Labour Relations Act, the intra-household nature of the relationship between domestic worker and employee, means that many employers do not implement the provisions of the legislation. Furthermore, many domestic workers are not aware of their rights and those that are aware fear reprisal from employers. Further, due to the dispersed nature of domestic work, monitoring of implementation is difficult."

It is pertinent to mention that labour rights are also especially important for domestic workers in South Africa (Barker, 1999). With the adoption of the Labour Relations Act 1995, (LRA), employees, including domestic workers were for the first time granted a right not to be unfairly dismissed (Benjamin, 2008). Employers, are for example no longer allowed to dismiss their domestic workers at will without ample procedure and notice prescribed in law, however various recent studies have confirmed that the conduct is still flourishing with impunities in workplaces (Ally, 2011).

Most of the instances of terminations and dismissals of domestic workers were unfair and impermissible. Employee falling pregnant or enrolling and becoming a member of a trade union and so on could be reason(s) for their dismissal (HRW, 2006).

Termination will be unfair if the employer fails to prove that the reason for the termination is fair and that it relates to the conduct or capacity of the employee or based on the employer's operational requirements (Chapman, 2006). The onus is on the employer to prove that the dismissal was carried out in accordance with a fair procedure (Theron, 2005). The essence of shifting the onus onto the employer is to provide a well-founded ample climate of protection for mostly invisible vulnerable and exploited domestic workers.

Sometimes, employers in domestic work sector sack and lay off workers without knowing whether such acts amount to a termination or a dismissal (Ntisa, 2013). This reason for this is that most of employers of domestic workers are not full blown companies with standard structures for administration and human resources to cater for employees. To this end, one could argue that majority of the employers and employees lack knowledge and are sometimes unable to differentiate between a termination and a dismissal (Barrow and Mosley, 2011). However, it should be pointed out that certain circumstances are determinant of these words and can be used interchangeably or not. For example, if a domestic worker is employed on a term contract, the employment becomes automatically terminated when the contract expires; this is not a dismissal (Kruppe, 2013). On the other hand, an employee who has been sacked could be described as being "terminated" or "dismissed" and it would fit the scenario (Lind, 2000). Whether terminated or dismissed, an employee would have the same rights in law against the employer by virtue of SD7. Irrespective of the terminology used, the labour court or adjudicating institution would critically examine and look into the circumstances of the termination or dismissal and come up with a decision based on the facts presented (Selala, 2011). To this end, it will not be out of place if sometimes, the words termination and dismissal are used interchangeably (Salman, 2005). These words are mere means to arrive at justice because they describe the wrongful acts. The complaints and facts presented by the parties during adjudication of the case will assist the court to attain justice.

\section{Literature Review}

Termination of employment of a domestic worker connotes that the worker is looked down upon and unceremoniously removed from the workplace for reason or reasons known to the employer. (Delport,1992). This notwithstanding, it is pertinent to point out that the worker has protective rights under the law against wrongful termination and as such can seek redress in the appropriate court (Blades, 1967). However, under the law, both parties can terminate the employment relationship (Rock and Wachter 1996), either as a result of the employee tendering resignation or removal from service by employer after giving notice or money as provided for in the contract of employment or the law (Cihon and Castagnera, 2008).

Termination means that the service being provided by the employee has come to an end and this may include dismissal and discharge (Fox and Hindman, 1993). However, unlike dismissal which is considered as negative, termination is not always negative (Martins, 2009).

Dismissal could be a temporary or permanent removal of an employee from the workplace as a punishment for wrongdoing (Harcourt et al. 2013). Unlike termination where the employee is entitled to gratuity, with regard to dismissal, such gratuity is not paid unless and until the employee institute an action in court whereby adjudicating body will review the case and if found in favour of the employee, then gratuity and reinstatement may be ordered (Brake, 1982).

Based on the stated above, it can be said that the main differences between termination and dismissal when not used interchangeably are that:

- Either party involved (employee or employer) can terminate the employment contract while dismissal is done 
by the employer (Segalla et al, 2001).

- When termination of employment occurs, the employee is entitled to gratuity, whereas, with regards to dismissal, such gratuity is not paid (Omehia, 2011).

Termination of an employment is an abrupt stop put to the employer/employee relationship by the employer (Bishara, 2010). At this stage, the employer authoritatively instructs and asks the employee to depart from the workplace and stops all dealings with the employer in and outside of the workplace (Falcone, 2010). This act of termination is colloquially being referred to as the employee being fired (Weiss, 2012). Termination in this sense connotes that the employer terminates the employment and could either be outright sacking or laid-off of the employee (Navaretta, 1995). If an employee is sacked, it is presumed that he or she must have been in the wrong for one reason or another and this might jeopardise the opportunity of getting another job in the future (Perritt, 1987). However, if an employee is laid off this is usually at the instance of the employer and the SD7 describes this in clause 27 as termination on the ground of "operational requirements" (Du Toit, 2010). The law allows this type of termination of employment and mandates the employer to pay all the benefits and entitlements to the employee.

With regard to domestic work, SD7 describes termination in a broader sense covering the scope of what notice should be given, how it should be given, the severance package, accommodation during the pendency of the notice and wages. These are all issues that must be duly considered before employer can claim that the termination is fair in law and that the employee is not disadvantaged as a result of his or her vulnerability.

The employment conditions, working environment and the status of those who perform domestic works are appalling as they are not appreciated, respected, treated well and/or paid well most times in the workplaces. Against the backdrop of hardships and difficulties faced by these workers "which frequently include little time off, long hours, lack of privacy, strenuous work, and substandard pay. Domestic service is seen as a low status job, which is menial, humiliating, and oppressive. Further, the physical (including sexual), emotional, economic, and political exploitation and abuse of domestic servants has been well-documented...Additionally, illegal employment is often used to impose excessive forms of exploitation on servants who already find themselves in precarious, coercive, and asymmetrical positions vis-à-vis employers and the state. Domestic service, then, is an enduring site of oppression based on class, race, gender, nationality and citizenship" (Glantz, 2005).

Ramirez-Machado (2003) points out that "given its social and economic invisibility and the accompanying low social status, domestic work is often exploitative. Amongst other major problems encountered at the workplace, domestic workers face: long hours of work, heavy workloads, lack of privacy, low salaries, inadequate accommodation and food (live-in workers), job insecurity, absence of benefits normally granted to other categories of workers, and exposure to violence and abuse. In addition, given the particular vulnerability attached to their situation, two groups of domestic workers tend to be exposed to even harder conditions of work: migrant and child domestic workers."

In the feudal past, householders perceive domestic workers as part of their property and claim ownership of them (Edel, 1982), this perception is still present to a large extent in today's society. Sensitised workers are therefore considered as rebel who should be terminated and sent parking out of the house of the employers (Hathaway, 2010). While this is prevalent, it is flagrant violation of the law and due process of the law should kick-in to rescue and salvage arbitrarily terminated and dismissed domestic workers on flimsy unfounded reasons or grounds.

Interestingly, South Africa is one of the countries that have legislatively protected domestic workers numbering a rough estimate of about 1.2 million mostly African and Coloured women who work as housekeepers, cooks and nannies, and another 200,000 men, mostly gardener from unfair labour practice (Kehler, 2013). These vulnerable workers have been granted new labour market protections, including the right to a written contract with their employers and the rights to paid leave, severance pay, and notice prior to dismissal and so on (Davidov, 2005).

\section{Termination of Employment under Sectoral Determination}

The SD7 prescribes a whole range of requirements and conditions which must be fulfilled by the parties involved especially the employers before termination can be considered valid and effective. As aptly put by Du Toit (2010:217) "comprehensive protection encompassing all these requirements is provided by Chapter VIII of the LRA and, in practice, it is one of the forms of protection that domestic workers have most actively utilised."

Apart from other pieces of legislation regulating unfair practices and termination of employment and dismissal in particular, in addition, SD7 specifically and explicitly provides for ample regulation on termination of employment and the procedures to be taken by the employer (Ally, 2011). To this end, these protective mechanisms have become mandatory and inevitable because domestic workers are vulnerable and are exposed to many abuses including arbitrary termination and dismissals (Ramirez-Machado, 2003). 
Clause 24 of the SD7 provides that a minimum dismissal notice period of one week must be given if the domestic worker has been employed for six months or less ( Dinkelman and Ranchhod, 2012). In terms of clause 24 of the SD7, if the domestic worker has been employed for more than six months, the dismissal notice must be given at least four weeks before the termination of the employment. The key word in this law is the word 'must' and as such, it is mandatory and incumbent on the employer to adhere strictly to the law otherwise there will be consequences for failure of noncompliance. More importantly, considering the essence and nature of the vulnerability of the employees in this sector, with regard to those of them who are live-in workers, clause 26 of the SD7 clearly mandates that the employer must provide accommodation for a period of one month for a live-in domestic worker if the contract of employment is terminated (Gaitskell et al. 1983).

Clause 26 goes further to state that if a domestic worker elects to remain in accommodation in terms of sub clause (8) after the employer has terminated the domestic worker's contract of employment, the employer may deduct for that period, $10 \%$ of the amount the employer is required to pay the employee in terms of this clause as the value of the accommodation. The payment of $10 \%$ by the employee to the employer therefore, in the time being, creates landlord and tenant relationship and the domestic worker will have to be accorded this right until the period expires thereafter vacates the premises. The purport and intent of this provision is to give live-in domestic workers time to arrange alternative accommodation in order not to render her homeless and be exposed to indignity (Ginsburg, 2011).

Other legislative provisions covering domestic work include protection against unfair labour practices in terms of Sections 185-186 of the LRA, of unfair dismissal in terms Sections 185-195 of the LRA and unfair discrimination in terms of Section 6 of the Employment Equity Act, No. 55 Of 1998 (EEA). The court has had an opportunity to adjudicate on whether a pregnant domestic worker had been treated unfairly when her employment was terminated and was out rightly dismissed as a result of her being pregnant. The court observed in the case of Ndlovu v Pather 2006) 27 ILJ 2671 (LC), that the applicant had been dismissed because she was pregnant and needed to attend a clinic regularly for check-ups. Her employer alleged that she had resigned. The Labour Court held that it was improbable that she (the domestic worker) had wanted to resign as she was in dire financial straits and needed to work for as long as possible. The outcome of the case was in the worker's favour. The court found that she had been dismissed for reasons relating to her pregnancy, amounting to an automatically unfair dismissal in terms of section 187 of the LRA, and she was awarded 20 months' remuneration as compensation.

The case of Ndlovu v Pather reinforced the significance and importance of the combined effect of the LRA and the EEA which seeks to show that an employer may not prevent a pregnant woman from entering the labour market, may not disadvantage her during the existence of the employment relationship and may not prematurely terminate her employment owing to her pregnancy and/or family responsibilities. Therefore, the court will frown at termination that is considered as gendered, discriminatory or targeting a particular group. Such terminations will be declared null and void by the court and the court will not hesitate to impose appropriate sanction against perpetrators and serve as a deterrent to would-be abusers and violators.

\section{Doing the Right Thing}

Even though, there is ample law regulating termination of the employment of domestic workers (Carlson, 1996), considering the fact that those who are in this occupation are illiterates, poor, uneducated and of lower status in the society, the employers should exercise restraints by not terminating their employment at will knowing very well that the parties involved do not have equal bargaining powers (Dias and Jayasundere, 2001).

More importantly, the economic backgrounds of the workers need to be put into consideration before termination is effected (Schenk, 2008). If the misconduct is trivial, it will not be necessary for the employer to use the sledge hammer to kill an ant just because of the vantage position. In this instance, the employer could sound a serious warning and tells the employee that should there be a repetition of the conduct, there will be consequences. However, if the employer insists on proceeding with termination, then, due process must be followed and the procedure stipulated in the SD7 will have to be followed to the letter.

Therefore, termination may only be considered and imposed if the conduct is so severe that continual employment of the employee could cause unimaginable harm to the employer. However, no matter the situation, the due process of the law will still have to be followed and applied, otherwise the employer will be in the wrong by acting against the regulatory frameworks that have been put in place for such purposes. SD7 in terms of clause 27 clearly provides that nothing affects the right of a dismissed domestic worker to dispute the lawfulness or fairness of the dismissal in terms of Chapter VIII of the Labour Relations Act, 1995, or any other law. 
In the event of termination, SD7 prescribes that previous services rendered should be recognised hence in terms of clause 28 , on termination of employment, a domestic worker is entitled to a certificate of service stating full and relevant information of the worker and the services rendered.

More importantly, an aspect of doing the right thing is well articulated in clause 27 of the SD7 which provides for severance pay for the purposes "operational requirements" which means requirements based on the economic, technological, structural or similar needs of an employer. A typical situation that will warrant dismissal based on "operational requirements" is described as including but not limited to when the employer "moves to another city or country; if the employer is no longer able to afford a domestic worker; if a child no longer requires a child-minder; if an employer moves to a smaller house and as a result no longer requires a domestic worker. While the employer can dismiss on these grounds, employers are mandated under the law to pay domestic worker who is dismissed for reasons based on the employer's operational requirements severance pay equal to at least one week's full pay for each completed year of continuous service with that employer. However, a domestic worker who unreasonably refuses to accept the employer's offer of alternative employment with that employer or any other employer is not entitled to severance pay in terms of sub-clause (2).

\section{Conclusion}

Termination of employment of a domestic worker could be in good or bad faith, however, what is essential is that the employer still needs to comply with the laid down procedure and the implicit provisions of SD7 due to the uniqueness of the occupation of domestic workers and the work they do. Whatever the reason or reasons for misbehaviour or misconducts the employers need to strictly adhere to the law considering the vulnerability of domestic workers in the workplaces. More importantly, the wrongfully terminated or dismissed domestic worker has ample recourse to seek appropriate remedy at the court of law and institutions set up to assist them to seek redress for arbitrary termination of employment.

\section{Recommendations}

Even though there is increasing need to ensure that laws are enforced against erring employers who arbitrarily terminate the employment of domestic workers, it is apparent that due to the invisibility and vulnerability of these workers, in most cases, they keep the abuses as secrets for fear of reprisals by the employers. In view of these acts of intimidations and exploitations by the employers, employers need to be sensitised and groomed in the acts of treating their domestic workers like human beings that possess respect, rights and dignities just like the employers themselves.

It is also important to point out that some employers in this sector act inhumanely considering the way and manner they treat their maids, housekeepers and other domestic workers. With regard to this, the law should take its full course against employer who perpetrates wilful and demeaning acts by arbitrarily terminating, without considering the implications and effects in law and the socio economic well-being on the worker. Perpetrators should therefore be brought to justice where their criminal and civil responsibilities will be explored in the appropriate tribunals and necessary sanctions imposed accordingly.

Domestic workers should also be sensitised on the need to carry out their duties as stipulated in law. In this regard, the trade union and appropriate sectors in the labour departments are enjoined to, from time to time, impress on them that domestic work is recognised as employment under the law and as such they have to discharge their duties in accordance with the law by not deliberately absconding from work without notice or approval, dereliction of duties and so on.

\section{References}

Ally S 2011. From servants to workers: South African domestic workers and the democratic state. New York, USA:Cornell University Press.

An update on labour law developments from the South African courts. Tydskrif vir die Suid-Afrikaanse Reg, 1: 128-151.

Barker FS 1999. On South African Labour Policies. South African Journal of Economics. 671): 1-14.

Barrow S, Mosley R 2011. The employer brand: Bringing the best of brand management to people at work. West Sussex, UK: John Wiley \& Sons Ltd.

Benjamin P 2008.

Informal Work and Labour Rights in South Africa. Industrial Law Journal, 29:1579-1589.

Bishara ND 2010. Fifty Ways to Leave Your Employer: Relative Enforcement of Covenants Not to Compete, Trends, and Implications for 
Employee Mobility Policy. University of Pennsylvania Journal of Business Law, 13:751-759.

Blades LE 1967. Employment at Will vs. Individual Freedom: On Limiting the Abusive Exercise of Employer Power. Columbia Law Review, 67(8): 1404-1435.

Brake CA 1982. Limiting the Right to Terminate at Will--Have the Courts Forgotten the Employer. Vanderbilt. Law Review, 35:201-209.

Carlson RR 1996. Variations on a Theme of Employment: Labor Law Regulation of Alternative Worker Relations. South Texas law Review, 37:661-672.

Chapman A 2006. Unfair Dismissal Law and Work Choices: From Safety Net Standard to Legal Privilege. The Economic and Labour Relations Review, 16(2):237-264.

Cihon P, Castagnera J 2008. Employment and labor law. Ohio, USA: South Western Cenage Learning Publications.

Davidov G 2005. Enforcement Problems in Informal Labor Markets: A View from Israel. Comparative Labour Law \& Policy, 27:3-14.

Delport E 1992.The legal position of domestic workers: A comparative perspective. The Comparative and International Law Journal, 25(2):181-207.

Dias, M Jayasundere R 2001. Sri Lanka: Good practices to prevent women migrant workers from going into exploitative forms of labour. From http://www.oit.org/wcmsp5/groups/public/---asia/---ro-bangkok/documents/publication/wcms_160552.pdf. (Retrieved on 15 January, 2014).

Dinkelman T, Ranchhod V 2012. Evidence on the impact of minimum wage laws in an informal sector: Domestic workers in South Africa. Journal of .Development Economics. 99(1): 27-45.

Edel M1982. Home ownership and working class unity. International Journal of Urban and Regional Research. 6(2):205-222.

Ewing DW 1989. Justice on the job: Resolving grievances in the non-union workplace. Boston, USA: Harvard Business School Press.

Falcone P 2010. 101 sample write-ups for documenting employee performance problems: A guide to progressive discipline \& termination. From http://books.google.co.za/books?hl=en\&lr=\&id=cthpvyaconmc\&oi=fnd\&pg=pr3\&dq=termination=monbcpgmct $\&$ sig $=44 m 3$ iesgpc4uc-ldkclhyuasac4\#v=onepage\&q\&f=false. (Retrieved on 14 June, 2013).

Fourie ES 2008. South African context, international law and regulation by the European Union. From http://www.scielo.org.za/ scielo.php?pid= S1727-37812008000400005\&script=sci_arttext. (Retrieved on 5 January 2014).

Fox JB, Hindman HD 1993. The model employment termination act: Provisions and discussion. Employee Responsibilities and Rights Journal, 6(1):33-44.

Gaitskell D, Judy Kimble, Moira Maconachie \& Elaine Unterhalter. Class, race and gender: domestic workers in South Africa. Review of African Political Economy. 10(27-28): 86-108.

Gaitskell D, Kimble J, Maconachie M, Unterhalter E. Class, race and gender: domestic workers in South Africa. Review of African Political Economy. 10(27-28):86-108.

Ginsburg R 2011. At Home with Apartheid: The Hidden Landscapes of Domestic Service in Johannesburg. Berkely, USA: University of Virginian Press.

Glantz NM 2005. Moving maids: dynamics of domestic service and development. From http://www.scielo.org.mx/ scielo.php?script=sci_arttext\&pid=S0188-77422005000100006. (Retrieved on 13 May, 2013).

Harcourt M, Hannay M, Lam H 2013. Distributive Justice, Employment-at-Will and Just-Cause Dismissal. Journal of Business Ethics. 115(2): 311-325.

Hathaway DA 2010. Can workers have a voice?: The politics of deindustrialization in Pittsburgh. Pennsylvania USA:The Pennsylvania University Press.

HRW 2006. Human Rights Watch. Swept Under the Rug: Abuses Against Domestic Workers Around the World. Joint International Law Program. From http://books.google.co.za/books?hl=en\&lr=\&id=svzklcsnn8ac\&oi=fnd\&pg=pp1\&dq==p-3lhbrd0c\&sig=prz7pktx1 dodoq-lbokpqncvda\#v=onepage\&q\&f=false. (Retrieved on 8 September, 2013).

Kehler J 2013. Women and poverty: the South African experience. Journal of International Women's Studies, 2013. From http://vc.bridgew.edu/jiws/vol3/iss1/3/. (Retrieved on 22 May, 2014).

Kruppe T, Rogowski R, Schömann K 2013. Labour Market Efficiency in the European Union: Employment Protection and Fixed Term Contracts. From http://books.google.co.za/books?hl=en\&lr=\&id=7_dpy2lqHylC\&oi=fnd\&pg=PP1\&dq=if+a. (Retrieved on 5 March, 2014).

Lind EA, Greenberg J, Scott KS 2000. The winding road from employee to complainant: Situational and psychological determinants of wrongful-termination claims. Administrative Science Quarterly September, 45(3):557-590.

Mantouvalou V 2006. Servitude and Forced Labour in the 21st Century: The Human Rights of Domestic Workers. Indiana Law Journal, 35(4): 395-414.

Martins PS 2009. Dismissals for cause: The difference that just eight paragraphs can make. Journal of Labor Economics, 27(2):257-269.

Martins PS 2009. Dismissals for Cause: The Difference That Just Eight Paragraphs Can Make. Journal of Labor Economics, 27(2): 257279.

Mashburn-Myrick I D 2012. Giving the Help the Silent Treatment: How Alabama's New Immigration Law Punishes Domestic Workers, Ignores Certain Employers, and Shortchanges Us All. Alabama Law Review, 64:443-452.

Navaretta M J 1995. Model Employment Termination Act--Meta--More Aptly the Menace to Employment Tranquility Act: A Critique. Stetson Law Review, 25:1027-1039.

Ntisa AA 2013. Contract of employment and its impact on the job security of domestic workers. From http://196.21.64.68/handle/10352/127. (Retrieved on 16 April, 2014).

Omehia CN 2011. Dismissal in Nigeria Labour Law. Port Harcourt, Nigeria: Ecolaw Publications. 
Perritt HH 1987. Wrongful Dismissal Legislation. From http://works.bepress.com/henry_perritt/68. (Retrieved on 23 April, 2013).

Ramirez-Machado JM 2003. Domestic work, conditions of work and employment: A legal perspective. From http://www.ilo.int/wcmsp5/groups/public/---ed_protect/---protrav/---travail/documents/publication/wcms_travail_pub_7.pdf. (Retrieved on 11 February, 2014).

Rock EB, Wachter ML 1996.The Enforceability of Norms and the Employment Relationship. University of Pennsylvania Law Review. 144(5):1913-1952.

Salman RK 2005. Concept of dismissal and natural justice: an essential correlation. University of llorin Law Journal, 2(2): 52-62.

Schenk B, Schenk H, Swanepoel B 2008. South African human resource management: Theory \& practice. Cape Town, South Africa: Juta \& Co Ltd.

Segalla M, Jacobs-Belschak G, Müller C 2001. Cultural influences on employee termination decisions: Firing the good, average or the old? European Management Journal, 19(1):58-72.

Selala KJ 2011. The enforceability of illegal employment contracts according to the Labour Appeal Court: comments on Kylie v CCMA 20104 SA 383 (LAC). Potchefstroom Electronic journal,14(2): 207-226.

Smit N, Fourie E 2010. Extending protection to atypical workers, including workers in the informal economy in developing countries. International Journal of Comparative Labour Law and Industrial Relations, Issue 26(1): 43-60.

Sexwale BMM 1994. Experiences of South African domestic workers. London UK:Taylor \& Francis Ltd.

Theron J 2005. Intermediary or Employer - Labour Brokers and the Triangular Employment Relationship. Industrial Law Journal, 26:618628.

Vosko LF 2000.Temporary work: The gendered rise of a precarious employment relationship. Toronto, Canada: University of Toronto Press.

Weiss JC 2012. Inferences in Employment Law Compared to Other Areas of the Law: Turning the Rules Upside Down. New York Law School Review, 57:781-789. 